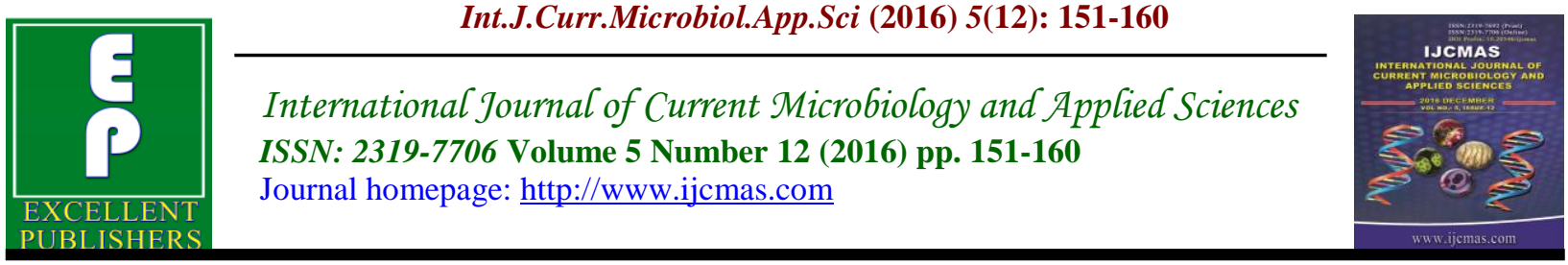

Original Research Article

http://dx.doi.org/10.20546/ijcmas.2016.512.017

\title{
Mitigation of Toxic Effects of Sodium Arsenate on Germination, Seedling Growth and Amylolytic Enzyme of Mungbean Seedlings with Macronutrients, Micronutrients and Organic Acids
}

\author{
Arpita Swarnakar* \\ Bangabasi College, University of Calcutta, West Bengal-700009, India \\ *Corresponding author
}

Keywords

Sodium arsenate, macronutrients, micronutrients, organic acids, mitigation, Vigna radiata.

\section{Article Info}

Accepted:

12 November 2016

Available Online:

10 December 2016

\section{A B S T R A C T}

Effect of sodium arsenate $\left(\mathrm{Na}_{2} \mathrm{HAsO}_{4} .7 \mathrm{H}_{2} \mathrm{O}\right)$ on the growth of mungbean seedlings was investigated and it was found to have drastic effects on the germination and growth of mungbean (Vigna radiata (L.) Wilczek cv. B-105) seedlings. Percentage of seed germination was found to decrease significantly with increasing concentrations $(5 \mu \mathrm{M}, 10 \mu \mathrm{M}$ and $20 \mu \mathrm{M})$ of arsenate. Reduction in seedling length - shoot length, root length, area of primary leaves, fresh weight and dry weight was also observed. Similar decreasing trend was also recorded in case of amylolytic enzyme activity i.e. amylase activity of the seedlings. However, reduction in seedling growth inhibition was achieved by pretreating the seeds with macronutrients $\left(\mathrm{KH}_{2} \mathrm{PO}_{4}, \mathrm{NaH}_{2} \mathrm{PO}_{4} \cdot 2 \mathrm{H}_{2} \mathrm{O}, \mathrm{K}_{2} \mathrm{SO}_{4}, \mathrm{CaCl}_{2} \cdot 2 \mathrm{H}_{2} \mathrm{O}, \mathrm{MgSO}_{4} \cdot 7 \mathrm{H}_{2} \mathrm{O}\right.$ at $10 \mathrm{mM}$ concentration), micronutrients $\left(\mathrm{ZnSO}_{4}, \mathrm{CuSO}_{4}, \mathrm{Na}_{2} \mathrm{MoO}_{4} \cdot 2 \mathrm{H}_{2} \mathrm{O}\right.$, $\mathrm{MnCl}_{2} \cdot 4 \mathrm{H}_{2} \mathrm{O}, \mathrm{CoCl}_{2} \cdot 6 \mathrm{H}_{2} \mathrm{O}, \mathrm{FeSO}_{4} \cdot 7 \mathrm{H}_{2} \mathrm{O}$ at $1 \mathrm{mM}$ concentration) and organic acids (pyruvate, citrate, malate, fumarate, succinate at $10 \mathrm{mM}$ concentration); best results were shown by $\mathrm{KH}_{2} \mathrm{PO}_{4}, \mathrm{NaH}_{2} \mathrm{PO}_{4}, \mathrm{CoCl}_{2}$ and Pyruvate from above mentioned three respective groups. These vital compounds used in the present study helped in the mitigation of arsenate induced growth inhibition to different degrees. Growth enhancement of seedlings caused by these two phosphate salts with different cations indicates that anion phosphate and not cations ( $\mathrm{Na}$ and $\mathrm{K}$ ) is responsible for the beneficial effect.

\section{Introduction}

Arsenic toxicity has gained at present an alarming global importance. Groundwater contamination by arsenic has been reported from many countries with the most severe problems occurring in Asia namely, Bangladesh, India, China and Taiwan. Among the numerous countries in different parts of the world affected by groundwater arsenic contamination, the largest population at risk is in Bangladesh followed by our state, West Bengal in India. In West Bengal, concentration of arsenic (As) in groundwater of some places has been found to be above the maximum permissible limit (recommended value by WHO and US EPA is $0.01 \mathrm{mg} / \mathrm{l}$ ) in 9 districts covering an area of 38,865 sq. $\mathrm{km}$. This is regarded as the biggest arsenic calamity in the world. Crop plants are also affected when irrigated in fields by arsenic contaminated groundwater, 
which is expressed with reduction in growth and yield.

Seed germination is the first and most critical stage in seedling establishment, determining successful crop production (Almansouri et al., 2001). Plants grown in presence of arsenate or arsenite show reduced seed germination and growth (Liu et al., 2005, Rahman et al., 2012). Elevated soil levels resulting from long term use of arsenic contaminated ground water for irrigation inhibit rice seed germination and seedling establishment. There are a number of studies investigating the effect of As on different plant species including rice (Abedin and Meharg, 2002) but little work has been done on mungbean crops. Percentage of seed germination is found to decrease significantly with increasing concentrations of arsenite and arsenate in comparison to control. Root growth and shoot height of rice seedlings were found to decrease with increasing concentrations of arsenate (Abedin and Meharg, 2002, Choudhuy et al., 2011). Arsenic inhibits the growth and fresh and dry biomass accumulation in maize plants and bean plants (Stoeva et al., 2004, 2005).

Pulse crop Mungbean, is also an important crop and principal source of protein in Indian diet. The mature seeds of mungbean contain as high as $24 \%$ protein. Yield of Mungbean is bound to suffer if As toxicity becomes prevalent in the productive cropland where it is grown.

Macroelements are regarded as indispensable plant nutrients which enter into the composition of the plant body itself. Among macroelements, phosphorus is a necessary constituent of many important metabolites. Phosphorus has another important role in the present context, as it inhibits arsenate uptake in plant system (Cox and Kovar, 2001). This is, because Arsenate is a chemical analog of phosphate $(\mathrm{Pi})$ which compete for the same sites in the soil and is taken up by $\mathrm{Pi}$ transporters. Evidence for this comes from physiological studies showing competitive inhibition of arsenate uptake by Pi (Abedin et al., 2002). Phosphorus has been used to ameliorate arsenic toxicity and several authors have noted a reduction in effectiveness of arsenic, as phosphorus levels increase, on a wide variety of crops (Meharg and Rahman, 1994).

Microelements are important constituents of mineral nutrition in plants. They are very essential for growth and development of seedlings. Manganese chloride was able to reverse mercuric chloride induced shoot growth inhibition completely in rice seedlings and the inhibition of root growth was reduced from 86 to $8 \%$ (Mukherji and Ganguly, 1974).

Organic acids have also been found to have ameliorative roles. Few observations are on record that shows the counteracting effects of organic acids on the inhibition caused by many heavy metals. Inhibitory effects of copper in Chlorella could be overcome by citric acid (Steeman- Nielsen and KampNeilsen, 1970) whereas toxic effects of $\mathrm{HgCl}_{2}$ on rice seedlings could be counteracted appreciably by malate, pyruvate and citrate (Mukherji and Ganguly, 1974).

Therefore, the present investigation was undertaken to examine the effect of different concentrations of sodium arsenate on the growth and development of munbean seedlings and to study the altered metabolism of the seedlings due to stress induced by arsenic (As) toxicity.

Macronutrients, micronutrients and organic acids were tried as pretreatment chemicals to combat the serious problem of arsenic toxicity and to provide a possible method of arsenic tolerance. 


\section{Materials and Methods}

\section{Percentage of Germination}

Germination percentage (GP) is an estimate of the viability of a population of seeds. The equation to calculate germination percentage is: $\mathrm{GP}=$ seeds germinated/total seeds $\mathrm{x} 100$. Mungbean (Vigna radiata (L.) Wilczek cv. B -105) seeds, collected from Pulses and Oilseed Research Station, Berhampore, Government of West Bengal, India were treated with $0.1 \%$ w/v $\mathrm{HgCl}_{2}$ solution for 2 min for surface sterilization and washed repeatedly with distilled water. Around 50 seeds were were allowed to germinate on petridishes lined with filter paper and sodium arsenate, $\mathrm{Na}_{2} \mathrm{HAsO}_{4} .7 \mathrm{H}_{2} \mathrm{O}$, (from Merck) used as test solution at concentrations $-5 \mu \mathrm{M}$, $10 \mu \mathrm{M}$ and $20 \mu \mathrm{M}$. The seeds soaked in distilled water served as control.

\section{Plant material and arsenic treatments}

Mungbean seeds were treated with $0.1 \%$ w/v $\mathrm{HgCl}_{2}$ solution for 2 min for surface sterilization and washed repeatedly with distilled water. The germinated seeds (about 20) were grown on petridishes lined with filter paper and sodium arsenate, $\mathrm{Na}_{2} \mathrm{HAsO}_{4} \cdot 7 \mathrm{H}_{2} \mathrm{O}$, (from Merck) used as test solution at concentrations $-5 \mu \mathrm{M}, 10 \mu \mathrm{M}$ and $20 \mu \mathrm{M}$ for 5 days at $30^{\circ} \mathrm{C}$. The $\mathrm{pH}$ of the solution was 6.5 throughout. The seeds treated with only distilled water for 5 days served as control. The seedlings were harvested after 5 days for further studies. The above mentioned arsenate concentrations are comparable to soil conditions and are environmentally relevant.

\section{Pretreatment with Chemical regulators}

For the amelioration of arsenate toxicity, seeds were pre- treated with Macronutrients $\left(\mathrm{KH}_{2} \mathrm{PO}_{4}, \quad \mathrm{NaH}_{2} \mathrm{PO}_{4} \cdot 2 \mathrm{H}_{2} \mathrm{O}, \quad \mathrm{K}_{2} \mathrm{SO}_{4}\right.$, $\mathrm{CaCl}_{2} \cdot 2 \mathrm{H}_{2} \mathrm{O}, \quad \mathrm{MgSO}_{4} \cdot 7 \mathrm{H}_{2} \mathrm{O}, \quad\left(\mathrm{NH}_{4}\right)_{2} \quad \mathrm{SO}_{4}$,
$\mathrm{NH}_{4} \mathrm{NO}_{3}$ solutions each at $10 \mathrm{mM}$ concentration), micronutrients $\left(\mathrm{ZnSO}_{4}\right.$, $\mathrm{CuSO}_{4}, \quad \mathrm{Na}_{2} \mathrm{MoO}_{4} \cdot 2 \mathrm{H}_{2} \mathrm{O}, \quad \mathrm{MnCl}_{2} \cdot 4 \mathrm{H}_{2} \mathrm{O}$, $\mathrm{CoCl}_{2} \cdot 6 \mathrm{H}_{2} \mathrm{O}, \mathrm{FeSO}_{4} \cdot 7 \mathrm{H}_{2} \mathrm{O}$ solutions) at $1 \mathrm{mM}$ concentration and organic acids (pyruvate, citrate, malate, succinate, fumarate each at $10 \mathrm{mM}$ concentration), collectively referred here as 'Chemical regulators', for $24 \mathrm{~h}$ and then transferred to sodium arsenate solution $(10 \mu \mathrm{M})$ for next 4 days, total germination time being maintained for 5 days in all the cases. Another set of seeds were pretreated with distilled water for $24 \mathrm{~h}$ (instead of chemical regulators) and then transferred to sodium arsenate solution $(10 \mu \mathrm{M})$ for next 4 days, total 5 days. This was done to observe the growth promoting effect of the chemical regulators in comparison to water. The set which received distilled water for 5 days served as control.

\section{Morphological studies}

After 5 days, arsenate induced damaging effects were observed and root length and shoot length of growing mungbean seedlings were measured in all the sets. Seedling length of 20 seedlings were determined after excising the cotyledons and averaged. Estimation of leaf area (primary leaves) was carried out using graph paper. Data were collected from 20 plants at a time that were selected randomly from the same set and then averaged. Fresh weight and dry weight of 10 seedlings were determined after excising the cotyledons and averaged.

For estimating dry weight, the seedlings were allowed to dry in an oven at $70^{\circ} \mathrm{C}$ for 3 days. Data were collected from 10 plants at a time that were selected randomly from the same set and then averaged. Treatment with distilled water only for 5 days served as control. All the experiments were repeated 5 times and analyzed statistically. 


\section{Assay of total amylase}

The extraction and assay procedure used for total amylase enzyme was described by Swain and Dekker (1996). Germinating seedlings were extracted in $0.02 \mathrm{M}$ tris- $\mathrm{HCl}$ $(\mathrm{pH} 7.4)$ containing $1 \mathrm{mM} \mathrm{CaCl} 2$ and $5 \mathrm{mM} \beta$ mercaptoethanol, the cell free extract was dialysed at $4^{\circ} \mathrm{C}$ against extraction buffer for $4 \mathrm{hrs}$. Total amylase activity was assayed after adding $19 \mathrm{mM} \mathrm{CaCl} 2$ to the dialyzed extract to bring the total concentration of $\mathrm{Ca}^{2+}$ ion to $20 \mathrm{mM}$.

The total amylase activity was expressed in terms of $\mathrm{mg}$ maltose liberated per $\mathrm{g}$ fresh tissue.

\section{Statistical analysis}

The experiments were carried out in a completely randomized design (CRD) with 5 replicates; each replica comprising a single petridish containing an average of 20 seeds. All the experiments were analyzed statistically using ANOVA Table (and expressed in Critical Difference at 5\%).

\section{Result and Discussion}

\section{Effect of arsenate on percentage of seedling germination}

The applied concentrations of sodium arsenate were found to have significant effect on the percentage of germination of Mungbean seedlings. Percentage of seed germination was found to decrease significantly with increasing concentrations of arsenate.

Inhibition to germination due to sodium arsenate toxicity was observed to be $48 \%$, $76 \%$ and $90 \%$ due to $5 \mu \mathrm{M}, 10 \mu \mathrm{M}$ and $20 \mu \mathrm{M}$ sodium arsenate respectively in comparison to the control set (Table 1).

\section{Effect of arsenate and Chemical regulators on the growth parameter of seedlings}

From the present work, it is well established that sodium arsenate, $\mathrm{As}(\mathrm{V})$, is very toxic for the growth of mungbean seedlings. It can inhibit growth at very small concentrations such as $5 \mu \mathrm{M}$. Roots were characteristically stubby and brittle and root tips gradually turned brown. In the present work, length of mungbean seedlings demonstrated an inverse relationship to the applied molar concentrations of sodium arsenate. Inhibition of elongation of mungbean seedlings started at a concentration of $5 \mu \mathrm{M}$ sodium arsenate solution and it was remarkably pronounced at $20 \mu \mathrm{M}$ (Table 1). The inhibition increased at higher doses, the effect being more pronounced on root than shoot. Seedling length declined with increasing concentrations of sodium arsenate; decline being $41 \%, 81 \%$ and $91 \%$ in case of shoot and $62 \%, 86 \%$ and $93 \%$ in case of root due to $5 \mu \mathrm{M}, 10 \mu \mathrm{M}$ and $20 \mu \mathrm{M}$ sodium arsenate respectively. Arsenic is primarily found more in the roots rather than in the shoots of plants. Similar reports regarding roots were also noted in alfalfa, lettuce and wheat, rice and other plants due to As toxicity (Azizur Rahman et al., 2007; Rofkar and Dwyer, 2011).

Chemical regulators used in the present study helped in the amelioration of arsenate induced growth inhibition to different degrees. Pretreatment of mungbean seeds with macronutrients could bring about maximum stimulation of seedling growth followed by micronutrients $\left(\mathrm{KH}_{2} \mathrm{PO}_{4}\right.$, $\mathrm{NaH}_{2} \mathrm{PO}_{4} \cdot 2 \mathrm{H}_{2} \mathrm{O}$ ). Amelioration of arsenic induced inhibition was possible to a large extent by using $\mathrm{KH}_{2} \mathrm{PO}_{4}$ and $\mathrm{NaH}_{2} \mathrm{PO}_{4}$ pretreatments where hypocotyl and root lengths measured quite close to water control. Both the chemicals, viz., $\mathrm{KH}_{2} \mathrm{PO}_{4}$ and $\mathrm{NaH}_{2} \mathrm{PO}_{4} \cdot 2 \mathrm{H}_{2} \mathrm{O}$ could reduce the arsenic 
induced inhibition of shoot growth to $27 \%$ and $30 \%$ respectively, as opposed to $80 \%$ in case of arsenate treated sets $(10 \mu \mathrm{M})$ and $74 \%$ in case of water pretreated sets (Table 2). Growth enhancement of seedlings caused by these two phosphate salts with different cations indicates that anion phosphate and not cations ( $\mathrm{Na}$ and $\mathrm{K}$ ) is responsible for the beneficial effect (Swarnakar and Mukherji, 2005). Similar results were obtained in Canola (Brassica campestris) where addition of higher dose of $\mathrm{P}(500 \mu \mathrm{M})$ in hydroponic solution could prevent the plant form As toxicity (Cox et al., 1996). Again, amelioration of arsenate toxicity was achieved only by pretreating the seeds with the above mentioned chemical regulators while post-treatment or simultaneous treatment of these chemical regulators (especially, macronutrients) with sodium arsenate bore no fruitful result (Swarnakar and Mukherji, 2005).

Among micronutrients best result was shown by pretreatment with $\mathrm{CoCl}_{2}$ where only $39 \%$ inhibition of shoot length and 49\% inhibition of root length was recorded as compared to water treatment $(73 \%$ inhibition of shoot length and $80 \%$ inhibition of root length) as shown in Table 3. Organic acids were also able to ameliorate arsenic induced toxicity in mungbean seedlings to some extent and pyruvate put forth the best result followed by malate (Table 4). In case of seeds pretreated with pyruvate $(10 \mathrm{mM})$, shoot and root growth inhibition was recorded to be only $51 \%$ and $60 \%$ respectively whereas inhibition of shoot and root growth due to water pretreatment was $74 \%$ and $82 \%$ respectively.

\section{Effect of arsenate and Chemical regulators on primary leaf area of mungbean seedlings}

The applied concentrations of sodium arsenate were found to have significant effect on the area of pair of primary leaves. Reduction of leaf area was observed to be $20 \%, 43 \%$ and $68 \%$ due to $5 \mu \mathrm{M}, 10 \mu \mathrm{M}$ and $20 \mu \mathrm{M}$ sodium arsenate respectively in comparison to the control set (Table 5). With the increase in concentration of sodium arsenate, subsequent reduction in the area of first pair of primary leaves was noted. Simultaneous reduction of leaf area of the treated seedlings is naturally a consequence of inhibition of cell division and cell enlargement (Zidan et al., 1990).

Chemical regulators used in the present study helped in the amelioration of arsenate induced primary leaf area reduction to different degrees. Pretreatment of mungbean seeds with macronutrients $\left(\mathrm{KH}_{2} \mathrm{PO}_{4}\right.$, $\mathrm{NaH}_{2} \mathrm{PO}_{4} .2 \mathrm{H}_{2} \mathrm{O}$ ) could bring about maximum stimulation of seedling growth (only $17 \%$ and $19 \%$ inhibition) followed by micronutrients, especially $\mathrm{CoCl}_{2} \quad(21 \%$ inhibition) and organic acids- Pyruvate (24\% inhibition).

\section{Effect of arsenate and Chemical regulators on fresh weight and dry weight of mungbean seedlings}

Treatment with sodium arsenate resulted in progressive decline of average fresh weight of 5 day old mungbean seedlings with increasing concentrations; decline being $19 \%, 62 \%$ and $82 \%$ due to $5 \mu \mathrm{M}, 10 \mu \mathrm{M}$ and $20 \mu \mathrm{M}$ sodium arsenate respectively in comparison to the control set.

Dry weights of 5 day old seedlings also decreased with increasing concentrations of sodium arsenate; decline being 13\%, 31\% and $50 \%$ due to $5 \mu \mathrm{M}, 10 \mu \mathrm{M}$ and $20 \mu \mathrm{M}$ sodium arsenate respectively in comparison to the control set (Table 5).

A greater reduction of fresh weight relative to the dry weight of the germinated 
seedlings, induced by As toxicity, is a common observation as drastic water loss takes place as an immediate effect of most of the abiotic and biotic stresses imposed. It appears that marked dehydration of seedlings is one of the effects associated with growth inhibition. Reduction in fresh and dry weight due to As toxicity has also been reported in tomato plants (Carbonell- Barrachina et al., 1995).

Pretreatment with three types of Chemical regulators did help in the amelioration of arsenate induced reduction in fresh weight and dry weight to some extent.

Pretreatment of mungbean seeds with macronutrients $\left(\mathrm{KH}_{2} \mathrm{PO}_{4}, \quad \mathrm{NaH}_{2} \mathrm{PO}_{4} .2 \mathrm{H}_{2} \mathrm{O}\right)$ could bring about maximum stimulation or in other words minimum inhibition of fresh and dry weight of mungbean seedlings followed by micronutrients, especially $\mathrm{CoCl}_{2}$ and then organic acids (pyruvate) in comparison to water pretreatment (Table 5). Among the organic acids tested here viz., pyruvate, citrate, malate, fumarate and succinate, only pyruvate treatment was found to reverse the arsenic toxicity to some extent followed by malate.

\section{Effect of sodium arsenate and chemical regulators on the activity of Amylase enzyme}

Different concentrations of sodium arsenate contributed significantly on total amylase activity. When recorded in table, the overall change represented a gradual decreasing trend. Maximum inhibition in enzymatic activity occurred due to the highest concentration and a gradual decline was observed due to increasing concentrations of sodium arsenate.

The activity of amylase decreased to the extent of $40 \%, 55 \%$ and $80 \%$ with $5 \mu \mathrm{M}$, $10 \mu \mathrm{M}$ and $20 \mu \mathrm{M}$ sodium arsenate respectively in comparison to control (Table$5)$.

Table.1 Effect of various concentrations of sodium arsenate $\left(\mathrm{Na}_{2} \mathrm{HASO}_{4}\right)$ on the germination and growth of mungbean seeds (growth time -5 days).

C.D. - Critical Difference.

\begin{tabular}{|c|c|c|c|c|c|c|}
\hline Treatment & $\begin{array}{c}\text { Germination } \\
\%\end{array}$ & $\begin{array}{c}\text { Inhibition } \\
\%\end{array}$ & $\begin{array}{c}\text { Shoot length } \\
(\mathrm{cm})\end{array}$ & $\begin{array}{c}\text { Inhibition } \\
\%\end{array}$ & $\begin{array}{c}\text { Root length } \\
(\mathrm{cm})\end{array}$ & Inhibition \% \\
\hline $\mathrm{H}_{2} \mathrm{O}$ (control) & 100 & - & 11.5 & - & 4.5 & - \\
\hline $\begin{array}{c}\mathrm{Na}_{2} \mathrm{HAsO}_{4} .7 \mathrm{H}_{2} \mathrm{O}, \mu \mathrm{M} \\
5\end{array}$ & 52 & 48 & 6.80 & 41 & 1.7 & 62 \\
\hline 10 & 24 & 76 & 2.2 & 80 & 0.6 & 87 \\
\hline 20 & 10 & 90 & 1.0 & 91 & 0.3 & 93 \\
\hline S.E. (mean) & 3 & - & 0.3 & - & 0.1 & - \\
\hline C.D. (5\%) & 2.42 & - & 0.62 & - & 0.37 & \\
\hline
\end{tabular}


Table.2 Effect of Pretreatment ( $24 \mathrm{hrs})$ with Macronutrients $(10 \mathrm{mM})$ on mungbean seeds prior to transfer to sodium arsenate $(10 \mu \mathrm{M})$ for a further period of 4 days. C.D. - Critical Difference.

[Total growth time -5 days]

\begin{tabular}{|c|c|c|c|c|}
\hline Treatment & $\begin{array}{c}\text { Shoot } \\
\text { length }(\mathrm{cm})\end{array}$ & $\begin{array}{c}\text { Inhibition } \\
\% \\
\end{array}$ & Root length $(\mathrm{cm})$ & $\begin{array}{c}\text { Inhibition } \\
\% \\
\end{array}$ \\
\hline Water (control) & 11.5 & - & 4.5 & - \\
\hline $\mathrm{Na}_{2} \mathrm{HASO}_{4} .7 \mathrm{H}_{2} \mathrm{O}$ continuous & 2.2 & 80 & 0.6 & 87 \\
\hline \multicolumn{5}{|l|}{ Pretreatment (24 hrs) with } \\
\hline $\mathrm{H}_{2} \mathrm{O}$ & 3.0 & 74 & 0.8 & 82 \\
\hline $\mathrm{KH}_{2} \mathrm{PO}_{4}$ & 8.4 & 27 & 3.3 & 26 \\
\hline $\mathrm{NaH}_{2} \mathrm{PO}_{4} \cdot 2 \mathrm{H}_{2} \mathrm{O}$ & 8.0 & 30 & 3.2 & 29 \\
\hline $\mathrm{K}_{2} \mathrm{SO}_{4}$ & 4.0 & 65 & 1.5 & 67 \\
\hline $\mathrm{CaCl}_{2} \cdot 2 \mathrm{H}_{2} \mathrm{O}$ & 3.5 & 70 & 2.7 & 40 \\
\hline $\mathrm{MgSO}_{4} \cdot 7 \mathrm{H}_{2} \mathrm{O}$ & 3.4 & 71 & 2.2 & 51 \\
\hline$\left(\mathrm{NH}_{4}\right)_{2} \mathrm{SO}_{4}$ & 3.2 & 72 & 2.0 & 56 \\
\hline $\mathrm{NH}_{4} \mathrm{NO}_{3}$ & 3.0 & 74 & 1.0 & 78 \\
\hline S.E.(mean) & 0.18 & _- & 0.15 & $=$ \\
\hline C.D. at $5 \%$ & 0.65 & - & 0.32 & - \\
\hline
\end{tabular}

Table.3 Effect of Pretreatment (24 hrs) with Micronutrients ( $1 \mathrm{mM})$ on mungbean seeds prior to transfer to sodium arsenate $(10 \mu \mathrm{M})$ for a further period of 4 days. C.D. - Critical Difference.

[Total growth time -5 days]

\begin{tabular}{|c|c|c|c|c|}
\hline Treatment & $\begin{array}{l}\text { Shoot length } \\
(\mathrm{cm})\end{array}$ & $\begin{array}{c}\text { Inhibition } \\
\%\end{array}$ & Root length $(\mathrm{cm})$ & $\begin{array}{c}\text { Inhibition } \\
\%\end{array}$ \\
\hline Water (control) & 11.5 & - & 4.5 & - \\
\hline $\begin{array}{l}\mathrm{Na}_{2} \mathrm{HASO}_{4} \cdot 7 \mathrm{H}_{2} \mathrm{O} \\
\text { continuous }\end{array}$ & 2.2 & 80 & 0.6 & 87 \\
\hline \multicolumn{5}{|c|}{ Pretreatment (24 hrs) with } \\
\hline $\mathrm{H}_{2} \mathrm{O}$ & 3.1 & 73 & 0.9 & 80 \\
\hline $\mathrm{CoCl}_{2} \cdot 6 \mathrm{H}_{2} \mathrm{O}$ & 7.0 & 39 & 2.3 & 49 \\
\hline $\mathrm{CuSO}_{4} .5 \mathrm{H}_{2} \mathrm{O}$ & 4.5 & 62 & 1.4 & 69 \\
\hline $\mathrm{MnCl}_{2} \cdot 4 \mathrm{H}_{2} \mathrm{O}$ & 4.4 & 62 & 1.7 & 62 \\
\hline $\mathrm{ZnSO}_{4}$ & 3.8 & 67 & 1.4 & 69 \\
\hline $\mathrm{Na}_{2} \mathrm{MoO}_{4} \cdot 2 \mathrm{H}_{2} \mathrm{O}$ & 3.5 & 70 & 1.7 & 62 \\
\hline $\mathrm{FeSO}_{4} .7 \mathrm{H}_{2} \mathrm{O}$ & 3.0 & 74 & 1.0 & 78 \\
\hline S.E.(mean) & 0.11 & _ & 0.09 & _ \\
\hline C.D. at $5 \%$ & 0.54 & - & 0.28 & 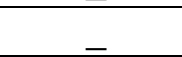 \\
\hline
\end{tabular}


Table.4 Effect of Pretreatment ( $24 \mathrm{hrs}$ ) with neutralized organic acids $(10 \mathrm{mM})$ on mungbean seeds prior to transfer to sodium arsenate $(10 \mu \mathrm{M})$ for a further period of 4 days. C.D. - Critical Difference.

[Total growth time -5 days]

\begin{tabular}{|l|c|c|c|c|}
\hline \multicolumn{1}{|c|}{ Treatment } & $\begin{array}{c}\text { Shoot length } \\
(\mathrm{cm})\end{array}$ & $\begin{array}{c}\text { Inhibition } \\
\%\end{array}$ & $\begin{array}{c}\text { Root length } \\
(\mathrm{cm})\end{array}$ & $\begin{array}{c}\text { Inhibition } \\
\%\end{array}$ \\
\hline Water, Control & 11.5 & - & 4.5 & - \\
\hline Sodium arsenate & 2.2 & 80 & 0.6 & 87 \\
\hline Pretreatment (24 h) with & & & & 82 \\
\hline $\mathrm{H}_{2} \mathrm{O}$ & 3.0 & 74 & 0.8 & 60 \\
\hline Pyruvate & 5.6 & 51 & 1.8 & 64 \\
\hline Citrate & 3.8 & 67 & 1.6 & 62 \\
\hline Malate & 4.2 & 63 & 1.7 & 78 \\
\hline Fumarate & 3.1 & 73 & 1.0 & 73 \\
\hline Succinate & 3.5 & 70 & 1.2 & - \\
\hline S.E.(mean) & 0.4 & - & 0.12 & - \\
\hline C.D. at 5\% & 0.45 & - & 0.22 & \\
\hline
\end{tabular}

Table.5 Effect of A) Sodium arsenate, As(V) and B) Chemical regulators (pretreatment for 1 day followed by transfer to sodium arsenate, $10 \mu \mathrm{M}$ for 4 days more) on Primary leaf area, Fresh weight, Dry weight and total amylase activity of 5 day old mungbean seedlings.

C.D. - Critical Difference.

\begin{tabular}{|l|l|l|l|l|l|l|l|l|}
\hline Treatment & $\begin{array}{l}\text { Primary } \\
\text { leaf area } \\
(\mathrm{sq} . \mathrm{mm})\end{array}$ & $\begin{array}{l}\text { Inhibition } \\
(\%)\end{array}$ & $\begin{array}{c}\text { Fresh } \\
\text { weight } \\
(\mathrm{g})\end{array}$ & $\begin{array}{c}\text { Inhibition } \\
(\%)\end{array}$ & $\begin{array}{c}\text { Dry } \\
\text { weight } \\
(\mathrm{g})\end{array}$ & $\begin{array}{c}\text { Inhibition } \\
(\%)\end{array}$ & $\begin{array}{c}\text { Total } \\
\text { amylase } \\
\text { activity* }\end{array}$ & $\begin{array}{c}\text { Inhibition } \\
(\%)\end{array}$ \\
\hline $\mathrm{A})$ Control & 108 & - & 3.27 & - & 0.32 & - & 20 & \\
\hline $5 \mu \mathrm{M} \mathrm{As}(\mathrm{V})$ & 76 & 30 & 2.04 & 38 & 0.21 & 34 & 12 & 40 \\
\hline $10 \mu \mathrm{M} \mathrm{As}(\mathrm{V})$ & 62 & 43 & 1.25 & 62 & 0.15 & 53 & 9 & 55 \\
\hline $20 \mu \mathrm{M} \mathrm{As}(\mathrm{V})$ & 35 & 68 & 0.62 & 81 & 0.14 & 56 & 4 & 80 \\
\hline $\begin{array}{l}\mathrm{B}) \text { Pretreatment } \\
(24 \mathrm{~h}) \text { with: }\end{array}$ & & & & & & & & \\
\hline $\mathrm{H}_{2} \mathrm{O}$ & 72 & 33 & 1.88 & 43 & 0.22 & 31 & & 10 \\
\hline $\mathrm{KH}_{2} \mathrm{PO}_{4}$ & 90 & 17 & 2.82 & 14 & 0.27 & 16 & 17 & 50 \\
\hline $\mathrm{NaH}_{2} \mathrm{PO}_{4}$ & 87 & 19 & 2.76 & 16 & 0.26 & 19 & 16 & 20 \\
\hline $\mathrm{CoCl}_{2}$ & 85 & 21 & 2.49 & 24 & 0.24 & 25 & 13 & 35 \\
\hline Pyruvate & 82 & 24 & 2.35 & 28 & 0.24 & 25 & 14 & 30 \\
\hline S.E.(mean) & 5 & - & 0.03 & - & 0.02 & - & 0.06 & \\
\hline C.D. at 5\% & 5.86 & & 0.280 & & 0.032 & & 2.82 & \\
\hline
\end{tabular}

*Total amylase activity $-\mathrm{mg}$ maltose released/g.fr.wt

[Control $=$ Water treatment $; \mathrm{H}_{2} \mathrm{O}=$ Treatment of seeds with water then transferred to As; Concentration of $\mathrm{KH}_{2} \mathrm{PO}_{4}, \mathrm{NaH}_{2} \mathrm{PO}_{4}$ and Pyruvate-10mM, $\mathrm{CoCl}_{2}-1 \mathrm{mM}$. Total period of growth -5 days] 
Inhibition of amylase activity in the mungbean seedlings in presence of sodium arsenate was reduced to some extent by pretreating the seeds with chemical regulators. Treatment with sodium arsenate $(10 \mu \mathrm{M})$ led to $55 \%$ decrease of amylase activity from that of control but when the seeds were pretreated with chemical regulators, only $15 \%$ decrease in amylase activity (activity quite close to control) was noted with $\mathrm{KH}_{2} \mathrm{PO}_{4}, 20 \%$ with $\mathrm{NaH}_{2} \mathrm{PO}_{4}$, $30 \%$ by pyruvate and $35 \%$ with $\mathrm{CoCl}_{2}$ in comparison to control (Table-5). Pretreatment with only water (instead of chemical regulators) could not help much to increase amylase activity and it recorded $50 \%$ decrease from control.

In conclusion, sodium arsenate is extremely toxic for plant growth. Among the three types of Chemical regulators used in the present investigation viz., Macronutrients, micronutrients and organic acids, few chemicals from each group like $\mathrm{KH}_{2} \mathrm{PO}_{4}$, $\mathrm{NaH}_{2} \mathrm{PO}_{4} .2 \mathrm{H}_{2} \mathrm{O}, \mathrm{CoCl}_{2}$ and pyruvate have emerged out to be effective ameliorative chemicals which possibly brought down the toxic effects of sodium arsenate in the Mungbean seedlings and thus their promoting effects on seedling growth parameters were well visible. Pretreatment with only water (instead of chemical regulators) could not help which indicates that chemical regulators do have some growth promoting roles over water and help in the reversal of altered metabolism induced by arsenate stress in Vigna radiata to different degrees. It may be suggested that pretreatment with these vital chemical regulators might have prepared the growing seedings to cope up with the arsenic toxicity in the early stages of growth. The concentration of Arsenic contaminated water in polluted sites often exceeds the concentration used in the present research work. Pretreatment of mungbean seeds with these chemical regulators might allow the seeds to germinate and initiate growth in arsenic contaminated water which in natural conditions leads to death of seedlings.

\section{Acknowledgement}

I am grateful to Prof. S. Mukherji, University of Calcutta, India, for his constant support and guidance. I am also indebted to Laboratory of Plant physiology, Dept. of Botany, University of Calcutta, for supplying all the necessary chemicals and instruments.

\section{References}

Abedin, M.J., and Meharg, A.A. 2002. Relative toxicity of arsenite and arsenate on germi-nation and early seedling growth of rice (Oryza sativa L.). Plant and soil, 243(1): 57-66.

Abedin, M.J., J. Feldmann and Meharg, A.A. 2002. Uptake Kinetics of As Species in Rice Plants. Plant Physiol., 128: 1120-1128.

Almansouri, M.J., M. Kinet and Lutts, S. 2001. Effect of salt and osmotic stresses on germination in durum wheat (Triticum durum Desf.) Plant Soil, 231: 243-254.

Carbonell - Barrachina, A.A., F. Burlo Carbonell, J. Mataix -Beneyto. 1995. Arsenic uptake, distribution and accumulation in tomato plants : effect of arsenite on plant growth and yield. J. Plant Nutr., 18(6) : 1237-1250.

Choudhury, B., S. Chowdhury and Biswas, A.K. 2011. Regulation of growth and metabolism in rice (Oryza sativa L.) by arsenic and its possible reversal by phosphate. J. Plant Interact., 6: 15-24.

Cox, M.S., and Kovar, J.L. 2001. Soil arsenic effects on canola seedling growth and ion uptake Communications in Soil Sci. Plant 
Analysis, 32: 107-117.

Cox, M.S., P.F. Bell, and Kovar, J.L. 1996. Differential tolerance of canola to arsenic when grown hydroponically or in soil. J. Plant Nutr., 19(12): 15991610

Liu, X., S. Zhang, X. Shan and Zhu, Y.G. 2005. Toxicity of arsenate and arsenite on germination seedling growth and amylolytic activity of wheat. Chemosphere, 61: 293-301.

Meharg, A.A. and Rahman, M.M. 1994. Phosphorus nutrition of arsenate tolerant and nontolerant phenotypes of velvetgrass. J. Environ. Qual., 23: 234-238.

Mukherji, S. and Ganguly, G. 1974. Toxic effects of Mercury in germinating rice seeds and their reversal. Indian J. Exp. Biol., 12: 432-434.

Rahman, M.A., H. Hasegawa, M.M. Rahman, M.N. Islam, M.A M. Miah, and Tasmen, A 2007.Accumulation of arsenic in tissues of rice plant (Oryza Sativa L.) and its distributions in fractions of rice grains. Chemosphere, 69, 942-948.

Rahman, M.M., M.A. Rahman, T. Maki and Hasegawa, H. 2012. Phytotoxicity of arsenate and salinity on early seedling growth of rice (Oryza sativa L.): A threat to sustainable rice cultivation in South and S E Asia. Bull. Environ. Contam. Toxicol., 88: 695-702.
Rofkar, R., J. and Dwyer, D. F. 2011. Effects of light regime, temperature and plant age on uptake of arsenic by Spartina pectinata and Carex stricta. Int. J. Phyto., 13: 528-537.

Steeman-Nielsen, E. and Kamp-Nielsen, L. 1970. Influence of deleterious concentrations of copper on the growth of Chlorella pyrenoidosa. Physiol. Plant, 23: 828-840.

Stoeva, N., M. Berova and Zlatev Z. 2004. Physiological response of maize to arsenic contamination. Biologia Plantarum, 47: 449-452.

Stoeva, N., M. Berova and Zlatev Z. 2005. Effect of arsenic on some physiological parameters in bean plants. Biologia Plantarum. 49 (2): 293-296.

Swain, R.R. and Dekker, E.E.C. 1996. Seed germination studies II. Pathway of starch degradation in germinating pea seedlings. Biochem. Biopys. Acta, 122: 87-100.

Swarnakar, A. and Mukherji, S. 2005 Amelioration of arsenic toxicity by phosphate salts in mungbean seedlings. J. Environ. Biol., 26(3): 551-555.

Zidan, I., I.I. Azaizen and Neuman P.M. 1990. Does salinity reduce growth in maize roots epidermal cells by inhibiting their capacity for cell wall acidification? Plant Physiol., 93: 7-11.

\section{How to cite this article:}

Arpita Swarnakar. 2016. Mitigation of Toxic Effects of Sodium Arsenate on Germination, Seedling Growth and Amylolytic Enzyme of Mungbean Seedlings with Macronutrients, Micronutrients and Organic Acids. Int.J.Curr.Microbiol.App.Sci. 5(12): 151-160. doi: http://dx.doi.org/10.20546/ijcmas.2016.512.017 